\title{
Diversity and Threatened Climber Plants in Tropical Forests of Courtallam Hills, Southern Western Ghats, India
}

\author{
E. Pandian* and P. Ravichandran \\ Department of Plant Science, Manonmaniam Sundaranar University, Tirunelveli, Tamil Nadu, India
}

Date Received: 26-11-2019

Date Accepted: 14-12-2019

\begin{abstract}
Investigated the distribution of climber and its conservation status in tropical forests of Courtallam hills in southern Western Ghats of Tamil Nadu, India during 2017-2018. A total of five 1 ha plots were established, and all climber species $\geq 1 \mathrm{~cm}$ diameter at breast height ( $\mathrm{dbh}$ ) were counted, which resulted in a total of 81 climbing plant species that representing to 62 genera under 30 families. Study plots revealed the most abundant climber species are Jasminum flexile (Oleaceae), Salacia oblonga (Celastraceae) and Ziziphus oenopolia (Rhamnaceae). The dominant climber species families in the study plots include Apocynaceae (11 species), Leguminosae (10 species), Menispermaceae and Vitaceae (6 species each), Capparaceae and Oleaceae (5 species each) and Convolvulaceae (4 species). Among 81 climber species, about 12 species are documented as threatened species of Courtallam hills. The results of this investigation suggest that forest management and forest protection is important for in-situ conservation of liana diversity with the involvement of local community.
\end{abstract}

Keywords: Climbing modes, conservation, threatened species, Western Ghats, Courtallam hills

\section{Introduction}

Lianas are woody climbers that are an abundant and diverse group of plants in tropical forests (Schnitzer and Bongers, 2002; Yang et al., 2018), where they comprise up to $32 \%$ of woody stems and $35 \%$ of woody species richness (Schnitzer et al., 2011; De Walt et al., 2015). The liana begins their life as self-supporting plants (Putz, 1984; Caballe, 1998) and providing a valuable food source for the associated fauna, physically linking trees together, furnishing canopy to canopy access for arboreal animals, tree regeneration and increasing tree mortality (Putz and Mooney, 1991; Schnitzer and Bongers, 2002). The lianas are largely used by local communities especially those surviving in nearby areas (Phillips, 1991; Bongers et al., 2002 Liu et al., 2004; 2005; Ewango, 2010; Muthumperumal and Parthasarathy, 2013). The climbing plants are found in all types of forests and all over the world, a few of climber studies have been carried out in the Western Ghats (Sarvalingam et al., 2011; Sarvalingam and Rajendran, 2012; 2016) and Eastern Ghats (Reddy and Parthasarathy, 2003; Parthasarathy et al., 2004; Muthumperumal and Parthasarathy, 2009; Seger and Hartz, 2014) of forests, India. Over the time period liana abundance has increased in various tropical forests in old-growth forests of western Amazonia (Phillips et al., 2002; Foster et al., 2008), the Guianas (Chave et al., 2008) and Central America (Wright et al., 2004; Ingwell et al., 2010; Schnitzer et al., 2012; Yorke et al., 2013). Moreover, evidences of climber species dominance in certain forest ecosystems i.e. temperate (Allen et al., 2007) and tropical (Phillips et al., 2002; Muthumperumal and Parthasarathy, 2009; Swaine and Grace, 2007) are also attributed to climate change (Malhi and Wright, 2005).

*Correspondence: pandianmahal1@gmail.com 
The abundance, species diversity and distribution of lianas are explained by several abiotic and biotic factors, including total rainfall, seasonality of rainfall, soil fertility, forest canopy structure and disturbance regimes (Addo-Fordjour et al., 2009a; 2009b; 2012; DeWalt et al., 2010; Ibarra-Manriquez and Martinez-Ramos, 2002; Poulsen et al., 2005; Schnitzer and Bongers, 2002; Schnitzer et al., 2005; Toledo, 2010; Vivek and Parthasarathy, 2016). Density of lianas ( $\geq 1.6 \mathrm{~cm}$ diameter) decreased with increasing altitude, whereas species richness was highest at intermediate elevations (Parthasarathy et al., 2004). Plant species richness and community composition may differ according to elevational gradient (Trigas et al., 2013), disturbance (Mohandass et al., 2015), and other environmental factors like climatic conditions (Tielborger et al., 2014).

Lianas play a major role in many aspects of forest functioning such as different patterns of pollination, dispersal and phenological systems, provide several resources and important role in the protection of biological diversity (Reddy and Parthasarathy, 2006) and they are well documented, since its fundamentally importance in the functioning of ecosystems as competing with trees either directly or indirectly, and they act as key ecological components of whole forest in transpiration, forest regeneration and carbon sequestration (Schnitzer and Bongers, 2002). The climbing species reveal a diversity of climbing mechanisms (Hegarty and Caballe, 1991) which is the best productive system of climbers and its overcome the trees for sunlight where they spread out the branches over the trees canopies (Campbell and Newbery, 1993). The small-scale of floristic surveys provide an effective method to explore forest structure and plant species composition within tropical forest communities (Castillo-Campos et al., 2008; Mohandass and Davidar, 2010; Refuge et al., 2016). However, climber communities have been neglected by most of studies, hence many of them emphasise greater attention on climber diversity only in recent years, particularly in India, because their conservation is threatened by anthropogenic disturbance from local communities residing beside the forest area and on the fringes of these reserves continue to be enormous (Mehta et al. 2008). Our study aim is to investigate the climber species diversity and their threatened status in tropical forests of Courtallam hills, southern Wastern Ghats, India.

\section{Methodology}

\subsection{The study area}

The present research work was conducted in Courtallam hills of southern Western Ghats (SWG) in Tirunelveli district of Tamil Nadu, India lies between 08.90211N" and 77.29772E" and 08.91093N" and $77.25842 \mathrm{E} "$ (Figure 1). Elevation range is around $500 \mathrm{~m}$ to $1,500 \mathrm{~m}$ and it has a diverse geographical and physical features such as hills and low plains, thorn-scrub jungles, rivers and cascades and thick inland forest. The mean daily maximum temperature is $30^{\circ} \mathrm{C}$. The weather is quite hot in May and June and the maximum temperature sometime reaches $39^{\circ} \mathrm{C}$. This region enjoys winter (December to March), summer (April to June), Southwest monsoon (June to September) and Northeast monsoon (October to November). The month of November generally receives maximum rainfall. Species were identified using various regional floras (Gamble and Fischer, 1915; 1935; Nair and Nayar, 1986; Hooker, 1872 to 1897). The composition of the soil in the Courtallam area as recorded by Nair and Nayar, (1986) is as follows: $18.1 \%$ gravel; dark brown sandy loam; $19.5 \%$ silt; $5.5 \%$ clay; $75 \%$ sand; water holding capacity $58.8 \%$; $\mathrm{pH} 6.1$; total soluble salt content $0.003 \%$ and organic carbon $2.2 \%$. 


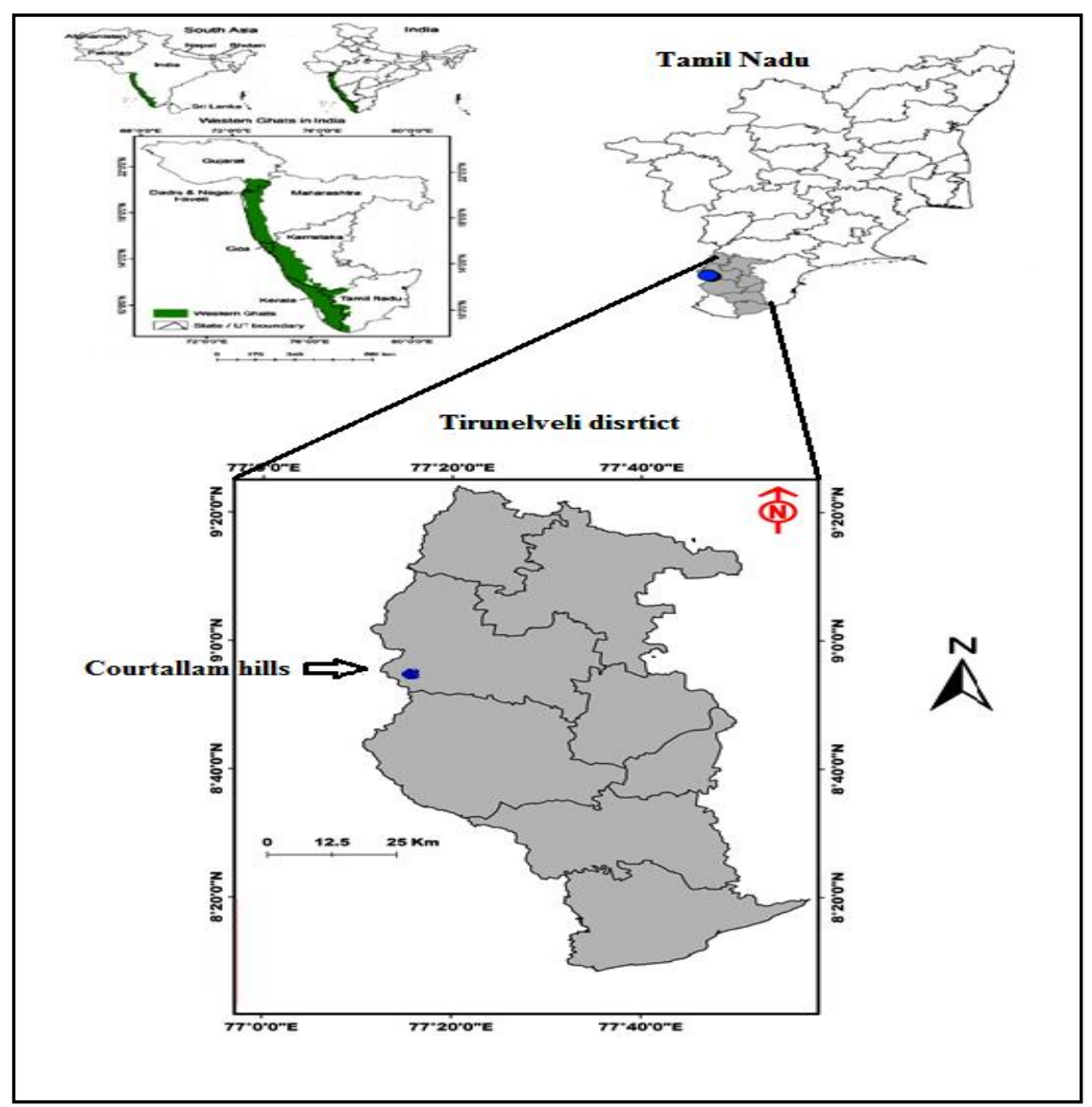

Figure 1. Map showing the location of Courtallam hills of southern western Ghats of India.

Enumeration of angiosperm climbing plants was carried in a total of 5 different forest plots to investigate the diversity and threatened climber plants species in tropical forests of Courtallam hills during 2017-2018. Five 1-ha plots $(100 \times 100 \mathrm{~m})$ were inventoried in different tropical forest plots, these plots were subdivided into two contiguous plots $(50 \times 100 \mathrm{~m})$. These sub-plots were again subdivided into fifty $10 \times 10 \mathrm{~m}$ quadrats for the quantitative assessment of climber species. All climber species with $\geq 1 \mathrm{~cm}$ diameter at breast height $(\mathrm{dbh})$ were measured at $1.3 \mathrm{~m}$ above ground level and their climbing mode (Putz, 1984) was recorded in the field itself and were classified into six categories viz. ST: Stem twiners; Str-A: Stragglers-armed; Str-UA: Stragglers-unarmed; TC: Tendril climbers; RC: Root climbers; and HC: Hook climber. The threatened status of the climber species was confirmed with IUCN Red list and also the help of using available RET (Rare, endangered and threatened species) data books and standard publications such as (Nair and Daniel, 1986; Nayar and Sastry, 1987; Nayar and Sastry, 1988; Nayar and Sastry, 1990; Walter and Gillet .1998; Sarvalingam and Rajendran, 2016). Voucher specimens were collected for each species and identified with local floras (Nair and Nayar, 1986; Hooker, 1872; 1897; Parkinson, 1923).

\section{Results and Discussion}

A total of 81 angiosperm climbing plants from 62 genera and 30 families were recorded in five 1 ha plots of Courtallam hills southern Western Ghats of India (Table 1). Sarvalingam and Rajendran (2016) reported a total of 285 climbing plant species belonging to 125 genera and 41 families from 
different forest types in the southern Western Ghats of Tamil Nadu, India and 60 liana species were recorded in Maruthamalai hills of southern Western Ghats (Sarvalingam and Rajendran, 2012) of Tamil Nadu. However, Muthumperumal and Parthasarathy (2009) recorded a total of 175 climbing plant species that belong to 100 genera and 40 families in tropical forests of southern Eastern Ghats, India. Seger and Hartz (2014) also conducted in northern Eastern Ghats of forests where 170 liana species were recorded, representing 109 genera and 43 families from 210 grids. A total of 169 species belonging to 60 families were encountered in the Cagarras Islands Natural Monument (CINM) located offshore of Rio de Janeiro, Brazil (Bovini et al., 2014), while Araujo and Alves (2010) also reported 93 climbing plant species were recorded in land Atlantic forest, northern Brazil, moreover in Upper Guinean forests documented 746 species of climbers (Jongkind and Hawthorne, 2005). Abundance and distribution pattern of lianas generally depends on abiotic factors such as elevation, rainfall and seasonality, soil fertility, and disturbance (Gentry, 1991; Balfour and Bond, 1993; Schnitzer and Bongers, 2002; Lu et al., 2009; Pandian and Parthasarathy, 2016). Our study plots revealed that the most abundant species are Jasminum flexile (Oleaceae), Salacia oblonga (Celastraceae) and Ziziphus oenopolia (Rhamnaceae) which data was pooled for the all the plots (Table 1). In other hand, Pterolobium hexapetalum (Caesalpiniaceae), Secamone emetica (Asclepiadaceae) and Premna villosa (Verbenaceae) were reported by Muthumperumal and Parthasarathy (2013) as most abundant species in the Western Ghats, while northern Eastern Ghats (Seger and Hartz, 2014) showed most dominant liana species such as Acacia sinuata (Mimosaceae), Bauhinia vahlii (Caesalpiniaceae), Calycapteris floribunda (Combretaceae) and Combretum albidum (Combretaceae). Strychnos minor (Loganiaceae) was dominant in the tropical dry evergreen forests (Parthasarathy et al., 2004) on the Coromandel Coast of India, interestingly those species did not occur in our sites.

The dominant climber speciose families in our sites include Apocynaceae (11 species), Leguminosae (10 species), Menispermaceae and Vitaceae (6 species each), Capparaceae and Oleaceae (5 species each) and Convolvulaceae (4 species) etc (Figure 2). This result accordance with Seger and Hartz (2014) who reported the most specious families, Convolvulaceae (23 species), Papilionaceae (22 species), Asclepiadaceae (19 species) and Cucurbitaceae (9 species) in northern Eastern Ghats of India. The common liana families are Cucurbitaceae, Papilionaceae, Asclepiadaceae and Convolvulaceae in Maruthamalia hills of Western Ghats (Sarvalingam and Rajendran, 2012). The families such as Smilacaceae, Passifloraceae, Menispermaceae, Cucurbitaceae and Convolvulaceae are totally dominated by plant species with a climbing habit (Araujo and Alves, 2010). In general, Apocynaceae, Anonaceae, Combrataceae, Fabaceae, Loganiaceae and Rutaceae lianas families were dominated in Asian forest (Cai et al., 2009; Dewalt et al., 2006; Mittermeier et al., 2004; Muthukumar et al., 2006; Muthuperumal and Parthasarathy, 2010; Sukumaran and Raj, 2007; Sarvalingam and Rajendran, 2016). Bovini et al., (2014) also reported, most dominated families are Asteraceae (12), Myrtaceae (12), Fabaceae (11), Euphorbiaceae (6), Cactaceae (6), Bromeliaceae (6), and Poaceae (6 species each) at Cagarras Islands Natural Monument (CINM) located offshore of Rio de Janeiro, Brazil. The most abundant liana species include the thorny stragglers, Ziziphus oenoplia (Rhamnaceae), Acacia caesia (Leguminosae), Capparis brevispina (Capparaceae), Carissa spinarum (Apocynaceae), Toddalia asiatica (Rutaceae), and the twiners Jasminum flexile (Oleaceae), Pyrenacantha volubilis (Icacinaceae), Ventilago maderaspatana (Rhamnaceae), Morinda umbellate (Rubiaceae) and Jasminum angustifolium (Oleaceae) (Table 1). This result coincides with Muthumperumal and Parthasarathy (2009) who also reported, thorny stragglers Pterolobium hexapetalum (Caesalpiniaceae), Lantana camara (Verbenaceae), Ziziphus oenoplia (Rhamnaceae), and the twiners Jasminum angustifolium (Oleaceae), Gymnema sylvestre, Secamone emetica (Asclepiadaceae) and Aganosma cymosa var. cymosa (Apocynaceae) in tropical forests of southern Eastern Ghats, India. 
Among 81 climber species, about 12 species are documented as threatened species which are Acacia caesia (Leguminosae), Aganosma cymosa (Apocynaceae), Ampelocissus latifolia (Vitaceae), Aristolochia tagala (Aristolochiaceae), Asparagus racemosus (Asparagaceae), Capparis diversifolia (Capparaceae), Cayratia pedata (Vitaceae), Coscinium fenestratum (Menispermaceae), Derris scandens (Leguminosae), Hemidesmus indicus (Apocynaceae), Salacia oblonga (Celastraceae) Smilax zeylanica (Smilacaceae) in Courtallam hills (Table.2). Karuppusamy and Ravichandran (2016) reported, a total of 486 woody plant species, of which 41 species are recorded as threatened species (IUCN) in Megamalai Wildlife Sanctuary in the southern Western Ghats of Theni district, Tamil Nadu and Sarvalingam and Rajendran (2016) also reported list of the rare, endangered and threatened (RET) of climbers in the southern Western Ghats of Tamil Nadu, India. Among the 81 species, few of the climber species (Abrus precatorius, Asparagus racemosus, Cissampelos pariera, Coccinea grandis, Hemidesmus indicus, Ichnocarpus frutescens and Tylophora indica) which are using as a medicinal plant by local people, this result coincides with Uma and Parthipan (2015) in Pazhayaru river bank of Kanyakumari District, Tamilnadu. Sarvalingam and Rajendran (2016) also reported in southern Western Ghats where few medicinal climbers are (Aganosoma cymosa, Aristolochia tagala and Coscinium fenestratum) using for curing skin diseases, cough, fever, headache, diabetes, asthma, dysentery and poison bites. Pictures of selected liana species are given in Figures (3-7). Plant binomial, family and voucher number of the 81 liana species are listed in Table 1.

The enumerated climbing plants were classified into two category woody vines, the lianas (69 species) and herbaceous vines (12 species). Seger and Hartz (2014) who also classified into two catenaries of lianas, woody vines (128 species) and herbaceous vines (42) in Eastern Ghats of India. The present study recorded six climbing mode of lianas were recognized: stem twiners (47\%) followed by stragglersarmed (24\%), stragglers unarmed (9\%), tendril climbers (14\%), root climbers $(2 \%)$ and hook climber $(2.5 \%)$. This climbing mode of lianas were similar with Muthumperumal and Parthasarathy (2009) and Seger and Hartz (2014) in tropical forests of Eastern Ghats, India. Several researchers have been reported that stem twiners were most common climbing plants in the different tropical forests (Parthasarathy et al., 2004; Kuzee and Bongers, 2005; Ghollasimood et al., 2012). Only one climbing mode, the grapnel-like climber (rattans) which was reported from Indian Western Ghats sites by Muthuramkumar and Parthasarathy (2000), did not occur in our study plots.

\section{Conclusion}

The climbers play an important role in the forest ecology and dynamics. A total of 81 climber species, 12 species were reported as threatened species in Courtallam hills. Many of climber species need effective care and proper conservation measures for their survival and long-term protection, because of forests are deteriorating under constant human activities. The present data of floristic diversity of climbers would be useful in species conservation and forest management and this data will be useful further scientific research for a global audience which is lead their effective protection.

\section{Acknowledgement}

Authors wish to thank DST-SERB-N PDF (PDF/2015/000874) for financial support.

\section{Reference}

Addo-Fordjour, P., Anning, A.K., Larbi, J.A. and Akyeampong, S., 2009a. Liana species richness, abundance and relationship with trees in the Bobiri forest reserve, Ghana: impact of management systems. Forest Ecology and Management, 257:1822-1828. 
Addo-Fordjour, P., Obeng, S., Addo, M.G. and Akyeampong, S., 2009b. Effects of human disturbances and plant invasion on liana community structure and relationship with trees in the Tinte Bepo forest reserve. Ghana. Forest Ecology and Management, 258:728-34.

Addo-Fordjour, P., Rahmad, Z.B. and Shahrul, A.M.S., 2012. Effects of human disturbance on liana community diversity and structure in a tropical rain forest, Malaysia: implication for conservation. Journal of Plant Ecology, 5:391-399.

Allen, B.P., Sharitz, R.R. and Goebel, P.C., 2007. Are lianas increasing in importance in temperate floodplain forests in the south eastern United States? Forest Ecology and Management, 242: 1723.

Araujo, D. and Alves, M., 2010. Climbing plants of a fragmented area of lowland Atlantic Forest, Igarassu, Pernambuco (Northeastern Brazil). Phytotaxa, 8:1-24.

Balfour, D. and Bond, W., 1993. Factors limiting climber distribution and abundance in a southern African forest. Journal of Ecology, 93-100.

Bongers, F., Parren, M.P.E. and Swaine, M.D., 2005. Forest climbing plants of West Africa: Intoduction. Forest climbing plants of West Africa: Diversity, Ecology and Management. Wallingford, Oxfordshire: CAB International, 5-18.

Bongers, F.J.J.M., Schnitzer, S.A. and Traore, D., 2002. The importance of lianas and consequences for forest management in West Africa. BioTerre, 59-70.

Bovini, M.G., Faria, M., Oliveira, R.R. and Kurtz B.R., 2014. Floristic diversity of the Cagarras Islands Natural Monument, Rio de Janeiro, Brazil. Check List, 10:366-373.

Caballe, G., 1998. Self-supporting capacity of tropical lianas: growth strategies. Canadian Journal of Botany, 76:1703-1716.

Cai, Z.Q., Schnitzer, S.A., Wen, B., Chen, Y.J. and Bongers, F., 2009. Liana communities in three tropical forest types in Xishuangbanna South-West China. Journal of Tropical Forest Science, 252-264.

Campbell, E.J.F. and Newbery, D.M., 1993. Ecological relationships between lianas and trees in lowland rain forest in Sabah, East Malaysia. Journal of Tropical Ecology, 9:469-490.

Castillo-Campos, G., Halffter, G. and Moreno, C.E., 2008. Primary and secondary vegetation patches as contributors to floristic diversity in a tropical deciduous forest landscape. Biodiversity and Conservation, 17:1701-1714.

Chave, J., Olivier, J., Bongers, F., Chatelet, P., Forgets, P.M., Peter van der Meer, Norden, N., Riera, B. and Dominique, P.C., 2008. Aboveground biomass and productivity in a rain forest of eastern South America. Journal of Tropical Ecology, 24:355-366.

DeWalt, S.J., Schnitzer, S.A., Alves, L.F., Bongers, F., Burnham, R.J., Cai, Z., Carson, W.P., Chave, J., Chuyong, G.B., Costa, F.R.C., Ewango, C.E.N., Gallagher, R.V., Gerwing, J.J., Amezcua, E.G., Hart, T., Ibarra-Manríquez, G., Ickes, K., Kenfack, D., Letcher, S.G., Macía, M.J., Makana, J.R., Malizia, A., Martínez-Ramos, M., Mascaro, J., Muthumperumal, C., Muthuramkumar, S., Nogueira, A., Parren, M.P.E., Parthasarathy, N., Pérez-Salicrup, D.R., Putz, F.E., Romero-Saltos, H.G., Sridhar Reddy, M., Sainge, M.N., Thomas,D. and Juliano van, M., 2015. Biogeographical patterns of liana abundance and diversity. 131-146. Ecology of lianas. John Wiley and Sons, New York, 131-146.

DeWalt, S.J., Ickes, K., Nilus, R., Harms, K.E. and Burslem, D.F.R.P., 2006. Liana habitat associations and community structure in a Bornean lowland tropical forest. Plant Ecology, 186:203-216.

DeWalt, S.J., Schnitzer, S.A., Chave, J., Bongers, F., Burnham, R.J., Cai, Z., Chuyong, G., Clark, D.B., Ewango, C.E.N., Gerwing, J.J., Gortaire, E., Hart, T., Ibarra-Manríquez, G., Ickes, K., Kenfack, D., Macía, M.J., Remy Makana, J., Martínez-Ramos, M., Mascaro, J., Moses, S., MullerLandau, H.C., Parren, M.P.E., Parthasarathy, N., Pérez-Salicrup, D.R., Putz, F.E., Romero-Saltos, 
H. and Duncan Thomas., 2010. Annual rainfall and seasonality predict pan-tropical patterns of liana diversity and basal area. Biotropica, 42:309-17.

Ewango, C.E.N., 2010. The liana assemblage of a Congolian rain forest: Diversity, structure and dynamics. Ph.D. Thesis. Wageningen: Wageningen University, 1-161.

Foster, J.R., Townsend, P.A. and Zganjar, C.E., 2008. Spatial and temporal patterns of gap dominance by low-canopy lianas detected using EO-1 Hyperion and Landsat Thematic Mapper. Remote Sensing Environ, 112:2104-2117.

Gamble, J.S. and Fischer, C.E.C., 1915-1935. Flora of the Presidency of Madras. Vols. I-III, Adlard and Co., London.

Gentry, A.H., 1991. The distribution and evolution of climbing plants. In: Putz FE, Mooney HA (eds) The biology of vines. Cambridge University Press, Cambridge, 3-52.

Gollasimood, S., Faridah-Hanum, I., Nazre, M. and Abd Kudus Kamziah., 2012. Abundance and distribution of climbers in a coastal hills forest in Perak, Malaysia. Journal of Agricultural Science, 4:245-254.

Hegarty, E.E. and Cabelle, G., 1991. Distribution and abundance of vines in forest communities In: Putz FE, Mooney HA. (eds.). The biology of vines. Cambridge University Press, Cambridge, 313-335.

Hooker, J.D., 1872-1897. The flora of British India. Vol. I-VII. L. Reeves and Co. London.

Ibarra-Manriquez, G. and Martinez-Ramos, M., 2002. Landscape variation of liana communities in a neotropical rain forest. Plant Ecology, 160:91-112.

Ingwell, L.L., Wright, S.J., Becklund, K.K., Hubbell, S. P. and Schnitzer, S.A., 2010. The impact of lianas on 10 years of tree growth and mortality on Barro Colorado Island, Panama. Journal of Ecology, 98:879-887.

Jongkind, C.C.H. and Hawthorne, W.D., 2005. A botanical synopsis of the lianes and other forest climbers; p. 19-39 In Bongers, F., Parren, M.P.E. and Traore, D. (ed.), Forest climbing plants of West Africa diversity, ecology and management. Cambridge. CABI Publishing.

Karuppusamy, S. and Ravichandran, V., 2016. Diversity Assessment of Woody Plants of Megamalai Wildlife Sanctuary, Theni District, Tamil Nadu. Bio Bulletin, 2:74-89.

Kuzee, M.E. and Bongers, F., 2005. Climber abundance, diversity and colonisation in degraded forests of different ages in Côte d'Ivoire: p. 67-84. In: Bongers, F., Parren, M.P.E. and Traore, D. (Eds.). Forest climbers of West Asia: Diversity, Ecology and Management. CABI Publishing.

Liu, W., Meng, F.R., Zhang, Y., Liu, Y. and Li, H., 2004. Water input from fog drip in the tropical seasonal rain forest of Xishuangbanna, South-West China. Journal of Tropical Ecology, 20:517524.

Lu, X.T., Tang, J.W., Feng, Z.L. and Li, M.H., 2009. Diversity and aboveground biomass of lianas in the tropical seasonal rain forests of Xishuangbanna, SW China. Revista de biología tropical. 57:211222

Malhi, Y. and Wright, J., 2005. Late twentieth-century patterns and trends in the climate of tropical forest regions. In: Malhi Y, Phillips O (eds). Tropical forests and global atmospheric change. Oxford University Press, Oxford.

Mehta, V.K., Sullivan, P.J., Walter, M.T., Krishnaswamy, J. and Degloria, S.D., 2008. Ecosystem impacts of disturbance in a dry tropical forest in southern India. Ecohydrology, 1:149-160.

Mittermeier, R.A., Myers, N. and Gill, P.C., 2004. Hotspots: Earth's Richest and Most Endangered Terrestrrial Ecoregions. Mexico City: CEMEX; SA, Agrupación Sierra Madre, SC.

Mohandass, D., Davidar, P., Somasundaram, S., Vijayan, L.A.L.I.T.H.A. and Beng, K.C., 2015. Influence of disturbance regime on liana species composition, density and basal area in the tropical montane evergreen forests (sholas) of the Western Ghats, India. Tropical Ecology, 56:169-182. 
Mohandass, D. and Davidar, P., 2010. The relationship between area, and vegetation structure and diversity in montane forest (shola) patches in southern India. Plant Ecology and Diversity, 3:6776.

Muthuramkumar, S., Ayyappan, N., Parthasarathy, N., Mudappa, D., Raman, T.S., Selwyn, M.A. and Pragasan, L. A., 2006. Plant community structure in tropical rain forest fragments of the Western Ghats India. Biotropica, 38:143-60.

Muthumperumal, C. and Parthasarathy, N., 2009. Angiosperms, climbing plants in tropical forests of southern Eastern Ghats, Tamil Nadu, India. Check List. 5:092-111.

Muthumperumal, C. and Parthasarathy, N., 2010. A large-scale inventory of liana diversity in tropical forests of South Eastern Ghats, India. Systematics and Biodiversity, 8:289-300.

Muthumperumal, C and Parthasarathy, N. 2013. Diversity, distribution and resource values of woody climbers in tropical forests of southern Eastern Ghats, India. Journal of forestry research, 24:365374.

Nair, K.K.N. and Nayar, M.P., 1986. Flora of Courtallam, Botanical survey of India. 441

Nair, N.C. and Daniel, P., 1986. Floristic diversity of the Western Ghats and its conservation: a review. Proceedings. Animal sciences-Indian Academy of Sciences.

Nayar, M.P. and Sastry, A.R.K., 1987. Red data book of Indian plants. BSI Calcutta, 1.

Nayar, M.P. and Sastry, A.R.K., 1990. Red data book of Indian plants, Botanical survey of India, Culcutta, CAMP. In CAMP Workshop, Shimla, 3.

Nayer, M.P. and Sastry, A.R.K., 1988. Red data book of Indian plants, vol. II. Botanical survey of India.

Pandian, E. and Parthasarathy, N., 2016. Decadal (2003-2013) changes in liana diversity, abundance and aboveground biomass in four inland tropical dry evergreen forest sites of peninsular India Journal of forestry research, 27:133-146.

Parkinson, C.E., 1923. A forest flora of the Andaman Islands, Govt. of India Press.

Parthasarathy, N., Muthuramkumar, S. and Reddy, M.S., 2004. Patterns of liana diversity in tropical evergreen forests of peninsular India. Forest Ecology and Management, 190:15-31

Phillips, O., 1991. The ethnobotany and economic botany of tropical vines. In: Putz, F.E., Mooney, H.A., editors. The Biology of vines. Cambridge: Cambridge University Press, 427-475.

Phillips, O.L., Martínez, R.V., Arroyo, L., Baker, T.R., Killeen, T., Lewis, S.L., Malhi, Y., Mendoza, A.M., Neill, D., Vargas, P.N., Alexiades, M., Ceron, C., Fiore, A.D., Erwin, T., Jardim, A., Placios, W., Saldias, M. and Vinceti, B., 2002. Increasing dominance of large lianas in Amazonian forests. Nature, 418:770.

Poulsen, A.D., Hafashimana, D., Eilu, G., Liengola, I.B., Ewango, C.E.N. and Hart, T.B., 2005. Composition and species richness of forest plants along the Albertine Rift, Africa. Biologiske Skrifter. 55:129-43.

Putz, F.E. and Mooney, H.A., 1991. The Biology of vines. Cambridge University Press.

Putz, F.E., 1984. The natural history of lianas on Barro Colorado Island Panama. Ecology, 65:1713-1724.

Reddy, M.S. and Parthasarathy, N., 2006. Liana diversity and distribution on host trees in four inland tropical dry evergreen forests of peninsular India. Tropical Ecology, 47:109-124.

Refuge, E.B., Forest, A. and Post, D., 2016. Floristic species composition and structure of a mid-elevation tropical montane evergreen forests (sholas) of the western Ghats, southern India. Tropical Ecology. 57:533-543.

Sarvalingam, A., Rajendran, A. and Aravindhan, V., 2011. Curative climbers of Maruthamalai hills in the southern Western Ghats of Tamil Nadu, India. International Journal of Medicinal and Aromatic Plants, 1:326-332.

Sarvalingam, A. and Rajendran, A., 2012. Diversity of liana species in Maruthamalai hills of southern Western Ghats, India. Phytotaxonomy. 12:131-135. 
Sarvalingam A, Rajendran A., 2016. Rare, Endangered and Threatened (RET) climbers of Southern Western Ghats, India. Revista chilena de historia natural, 89:9.

Schnitzer, S.A. and Bongers, F., 2002. The ecology of lianas and their role in forests. Trends in Ecology and Evolution, 17:223-230.

Schnitzer, S.A. and Bongers, F., 2011. Increasing liana abundance and biomass in tropical forests: emerging patterns and putative mechanisms. Ecology Letters, 14:397-406.

Schnitzer, S.A., DeWalt, S.J. and Chave, J., 2006. Censusing and Measuring Lianas: A Quantitative Comparison of the Common Methods1. Biotropica, 38:581-591.

Schnitzer, S.A., Kuzee, M.E. and Bongers, F., 2005. Disentangling above- and below-ground competition between lianas and trees in a tropical forest. Journal of Ecology, 93:1115-1125.

Schnitzer, S.A., Mangan, S.A., Dalling, J.W., Baldeck, C. A., Hubbell, S.P., Ledo, A., Muller-Landau, H., Tobin, M.F., Aguilar, S., Brassfield, D., Hernandez, A., Lao, S., Perez, R,. Valdes, O. and Yorke, S.R., 2012. Liana abundance, diversity, and distribution on Barro Colorado Island, Panama. PloS one. 7: e52114.

Walter, K.S. and Gillet, H.J., 1998. IUCN Red List of Threatened Plants. Compiled by the world conservation monitoring centre. IUCN-The world conservation union, Gland, Switzerland and Cambridge, UK. 862.

Seger, G.D.D.S. and Hartz, S.M., 2014. Checklist of climbing plants in an Araucaria forest of Rio Grande do Sul State, Brazil. Biota Neotropica, 14.

Sukumaran, S. and Raj, A.D.S., 2007. Rare, endemic, threatened (RET) trees and lianas in the sacred groves of Kanyakumari district. Indian Forester, 133:1254-1266.

Swaine, M.D. and Grace, J., 2007. Lianas may be favoured by low rainfall: evidence from Ghana. Plant Ecology. 192:271-276.

Tielborger, K., Bilton, M.C., Metz, J., Kigel, J., Holzapfel, C., Lebrija-trejos, E., Konsens, I., Parag, H.A. and Sternberg, M., 2014. Middle-Eastern plant communities tolerate 9 years of drought in a multisite climate manipulation experiment. Nature Communication, 5:5102.

Toledo, M., 2010. Neotropical lowland forests along environmental gradients. Ph.D. Thesis, Wageningen University.

Trigas, P., Panitsa, M. and Tsiftsis, S., 2013. Elevational gradient of vascular plant species richness and endemism in Crete-the effect of post-isolation mountain uplift on a continental island system. PLoS One. 8:e59425.

Uma, R. and Parthipan B., 2015. Survey on medico-botanical climbers in Pazhayaru river bank of Kanyakumari District, Tamilnadu. Journal of Medicinal Plants Studies, 3:33-6.

Vivek, P. and Parthasarathy, N., 2014. Liana community and functional trait analysis in tropical dry evergreen forest of India. Journal of Plant Ecology, 8:501-512.

Wright, S.J., Calderon, O., Hernandez, A. and Paton, S., 2004. Are lianas increasing in importance in tropical forests? A 17-year record from Panama. Ecology, 85:484-489.

Yang, S.Z., Fan, H., Li, K.W. and Ko, T.Y., 2018. How the diversity, abundance, size and climbing mechanisms of woody lianas are related to biotic and abiotic factors in a subtropical secondary forest, Taiwan. Folia Geobotanica, 1-12.

Yorke, S.R., Schnitzer, S.A., Mascaro, J., Letcher, S.G. and Carson, W.P., 2013. Increasing liana abundance and basal area in a tropical forest: the contribution of long-distance clonal colonization. Biotropica, 45:317-324. 